\section{Effect of Fluoride-Releasing Adhesive Systems on the Mechanical Properties of Eroded Dentin}

Ana Paula Albuquerque Guedes ${ }^{1}$, Mariana Dias Moda², Thaís Yumi Umeda Suzuki ${ }^{3}$, André Gustavo de Lima Godas ${ }^{2}$, Renato Herman Sundfeld ${ }^{2}$, André Luiz Fraga Briso², Paulo Henrique dos Santos ${ }^{3}$

\begin{abstract}
The aim of the study was to evaluate the effect of erosive $\mathrm{pH}$ cycling with solutions that simulate dental erosion on Martens hardness (HMV) and elastic modulus (Eit) of dentin restored with fluoride-releasing adhesive systems. Twenty-seven bovine dentin slabs were restored with three adhesive systems: Adper Single Bond 2 total-etch adhesive system, One Up Bond F and Clearfil SE Protect fluoride-containing self-etching adhesive systems. The restorations were made with Filtek Z250. The HMV and Eit values at distances of 10, 30,50 and $70 \mu \mathrm{m}$ from the interface were evaluated using a dynamic ultra microhardness tester before and after immersion in deionized water, citric acid and hydrochloric acid $(n=9)$. Data were submitted to repeated-measures ANOVA and Fisher's PLSD tests $(\square=0.05)$. After erosive cycling, HMV values of dentin decreased in all groups. For dentin restored with Adper Single Bond 2, the lowest values were found closer to the hybrid layer, while for One Up Bond F and Clearfil SE Protect, the values remained unaltered at all distances. For dentin restored with fluoride-releasing adhesive systems, a decrease in Eit was found, but after $30 \mu \mathrm{m}$ this difference was not significant. The acid substances were able to alter HMV and Eit of the underlying dentin. For fluoride-releasing adhesives, the greater the distance from bonded interface, the lower the Eit values. The fluoride in One Up Bond F and Clearfil SE Protect was able to protect the underlying dentin closer to the materials. In this way, the fluoride from adhesive systems could have some positive effect in the early stages of erosive lesions.
\end{abstract}

\author{
'Department of Prosthodontics, \\ UFES - Universidade Federal do \\ Espírito Santo, Vitória, ES, Brazil \\ ${ }^{2}$ Department of Restorative Dentistry, \\ Dental School of Araçatuba, \\ UNESP - Universidade Estadual \\ Paulista, Araçatuba, SP, Brazil \\ ${ }^{3}$ Department of Dental Materials \\ and Prosthodontics, Dental \\ School of Araçatuba, UNESP - \\ Universidade Estadual Paulista, \\ Araçatuba, SP, Brazil.
}

Correspondence: Paulo Henrique dos Santos, Rua José Bonifácio, 1193, 16015-050 Araçatuba, SP, Brasil. Tel: +55-18-3636-2802. e-mail: paulosantos@foa.unesp.br

Key Words: erosion, dentin, adhesive system, fluoride.

\section{Introduction}

Since the $19^{\text {th }}$ century, an increase in both the incidence and the prevalence of dental erosion has been well documented, especially among young adults $(1,2)$. The contact of the dental surface with known acids from extrinsic or intrinsic origins may promote irreversible loss of this substrate, which in turn leads to the formation of non-carious lesions, such as dental erosion (1). This is a multifactorial condition with a complex etiology (3).

Among the extrinsic etiological factors causing dental erosion, the most important is diet, which may include beverages and foods with erosive potential for the dental surface. Citric acid is the main acid contained in fruit juices and soft drinks and has high dissolving power. In addition to diet, certain occupations, such as working in a battery factory or lead sealing industry, and sports drinks can result in tooth erosion (3-5). The intrinsic factors causing dental erosion are caused mainly by stomach acid in contact with the oral cavity due to chronic vomiting or regurgitation. Gastroesophageal reflux occurs because of an involuntary movement of gastric contents towards the mouth due to some anomaly in the gastrointestinal tract. In general, the loss and demineralization of dental mineralized tissues occur when the hydrochloric acid from the gastric content reaches the oral cavity and remains there for a period of time (3).

Initially, erosive wear causes softening of the enamel. This process dissolves continuously the layers of enamel crystals, leading to a permanent loss of tissue that could reach the dentin (3). Dentin is a much more soluble substrate than enamel, since its mineral content is much lower ( $47 \%$ by volume) and its organic content is higher ( $>33 \%$ by volume) (6), making it sensitive to thermal and tactile stimuli. In these situations, the patient requires restorative treatment. It would be desirable if the used restorative materials addressed the erosive challenges and protected the dentin.

Many recent studies have sought to understand the remineralization of enamel after a cariogenic challenge (7). Based on this, several fluoride-releasing restorative materials have been introduced as an attempt to prevent demineralization (8). The fluoride released by adhesive systems could exert anticariogenic activity by increasing the strength of dentin against the acid attacks in the oral environment (9). Nakajima et al. (10) suggested that slowrelease fluoride in adhesive systems could increase the 
concentration of fluorapatite in the hybrid layer underlying dentin. Furthermore, they also reported that fluoride linked to apatite could show a prolonged effect, since fluorapatite is less soluble than sodium fluoride. Ferracane et al. (11) and Han et al. (12) detected fluoride from adhesive systems in the hybrid layer and its adjacent dentin, even after several weeks of immersion in water. These studies seem to speculate that fluoride in these adhesive systems could prevent degradation of dentin and result in stability of the adhesive interface. However, the mechanisms and efficacy of fluoride derived from restorative materials are still uncertain. Costa et al. (13) quantified the fluoride ions in demineralization/remineralization solutions and concluded that fluoride from these materials was released in very low concentrations, probably restricted to a small portion of dentin/composite interface exposed in the solutions.

It is thus important to evaluate whether this same fluoride could act in the process of demineralization/ remineralization of erosive lesions in early stages. Therefore, the aim of this study was to evaluate the Martens hardness (HMV) and elastic modulus (Eit) values of the underlying dentin from adhesive systems containing fluoride, which would then be subjected to a model of erosive $\mathrm{pH}$ cycling $\Xi$ that simulated the early stages of erosion from either extrinsic or intrinsic factors. The tested hypotheses were: 1) the acid substances (citric and hydrochloric acid) could modify the HMV and Eit values of the underlying dentin from adhesive systems; 2) differences in the mechanical properties of dentin could be found at different distances from the adhesive interface; and 3) the difference in the composition of restorative materials may interfere in the HMV and Eit values of the underlying dentin.

\section{Material and Methods}

\section{Sample Preparation}

Twenty-seven bovine teeth, freshly extracted and stored in a $0.1 \%$ tymol solution at $4{ }^{\circ} \mathrm{C}$ for a maximum of 30 days, were selected for this study. Dentin blocks measuring $6.0 \times$ $6.0 \mathrm{~mm}$ were obtained using a metallographic cutter (Isomet 2000, Buehler, Aurora, OH, USA). The enamel was removed with \#320 abrasive silicon carbide sandpaper (Extec Corp., Enfield, CT, USA) to complete the exposure of dentin.

Teeth were divided into three groups, according to the used adhesive system (Table 1).

Group 1: Teeth were etched with 32\% phosphoric acid (Bisco Inc., Schaumburg, IL, USA) for $15 \mathrm{~s}$, washed with deionized water and dried with smooth air jet. Two layers of Adper Single Bond 2 adhesive system (3M ESPE Dental Products, St. Paul, MN, USA) were applied on the etched surface, then the material was light-cured for $20 \mathrm{~s}$ using Ultraled (Dabi Atlante, Ribeirão Preto, SP, Brazil), with light intensity output of $500 \mathrm{~mW} / \mathrm{cm}^{2}$.

Group 2: Teeth received One Up Bond F self-etching adhesive system containing fluoride (Tokuyama Dental Corp, Tokyo, Japan). Bonding material A was mixed with bonding material $B$, then applied on the dentin surface and light-cured for $20 \mathrm{~s}$ with Ultraled (Dabi Atlante).

Group 3: Teeth received Clearfil SE Protect self-etching adhesive system containing fluoride and antibacterial agent (Kuraray Medical Inc, Kurashiki, Japan). The primer and bond were applied on the dentin surface and light-cured for 20 s using Ultraled (Dabi Atlante).

Three 2-mm increments of Filtek Z250 composite resin (3M Espe Dental Products) were inserted on the dentin and each increment was light-cured for $40 \mathrm{~s}$. After 24 $\mathrm{h}$ of storage in distilled water at $37^{\circ} \mathrm{C}$, the blocks were cut into three longitudinal slices using an Isomet 2000 metallographic cutter (Buehler). Samples were embedded in acrylic resin (Clássico, São Paulo, SP, Brazil), worn out manually with \#600, \#800 and \#1200-grit silicon carbide sandpaper, and polished with wet felt containing diamond pastes for 4 min on each step. Finally, the samples were cleaned in an ultrasonic cube containing deionized water for $5 \mathrm{~min}$ between the sandpapers, and again at the end of

Table 1. Composition of adhesive systems

\begin{tabular}{|c|c|c|}
\hline Material & Composition & Manufacturer \\
\hline Adper Single Bond 2 & $\begin{array}{l}\text { Etchant: 35\% phosphoric acid. Primer \&t Adhesive resin: bisphenol A diglycidyl } \\
\text { methacrylate, 2-hydroxyethyl methacrylate, ethanol, water, urethane dimethacrylate, } \\
\text { bisphenol A glycerolate, polyalkenoic acid copolymer, dimethacrylate, camphorquinone. }\end{array}$ & $\begin{array}{l}\text { 3M ESPE, St } \\
\text { Paul, MN, USA }\end{array}$ \\
\hline One Up Bond F & $\begin{array}{l}\text { Bonding A: Water, methyl methacrylate, 2-hydroxyethyl methacrylate, } \\
\text { coumarin dye, metacryloyloxyalkyl acid phosphate, methacryloxyundecane } \\
\text { dicarboxylic acid. Bonding B: multifuntional methacrylic monomer, } \\
\text { fluoraluminosilicate glass, photoinitiator (arylborate catalyst). }\end{array}$ & $\begin{array}{l}\text { Tokuyama Dental } \\
\text { Corp, Tokyo, } \\
\text { Japan }\end{array}$ \\
\hline Clearfil SE Protect & $\begin{array}{l}\text { Primer: 10-methacryloyloxydecyl dihydrogen phosphate, 12-methacryloyloxydodecylpyridinium } \\
\text { bromide, hydrophilic aliphatic dimethacrylate, water, initiators, accelerators, dyes, } \\
\text { others. Bond: bisphenol a diglycidyl methacrylate, 2-hydroxyethyl methacrylate, } \\
\text { sodium fluoride, 10-methacryloyloxydecyl dihydrogen phosphate, hydrophobic aliphatic } \\
\text { dimethacrylate, colloidal silica, dl-camphorquinone, initiators, accelerators, others. }\end{array}$ & $\begin{array}{l}\text { Kuraray Medical } \\
\text { Inc, Kurashiki, } \\
\text { Japan }\end{array}$ \\
\hline
\end{tabular}


the process to remove residue from previous granulation sandpaper.

\section{Mechanical Properties of Dentin}

After polishing the samples, the restored dentin blocks were examined by a dynamic ultra micro hardness tester (DUH-211S; Shimadzu, Kyoto, Japan) to check the HMV (Martens hardness obtained with the Vickers indenter) and elastic modulus (Eit values) of dentin under a load of $3 \mathrm{mN}$ at a speed of $0.2926 \mathrm{mN} / \mathrm{s}$, for $5 \mathrm{~s}$, at the following distances from restorative interface: $10 \mu \mathrm{m}, 30 \mu \mathrm{m}, 50 \mu \mathrm{m}$ and $70 \mu \mathrm{m}$ $\mathrm{m}$. Three indentations in all the studied regions were made with a Vickers tip. The HMV value $\left(\mathrm{N} / \mathrm{mm}^{2}\right)$ was defined as the maximum force ( $F$ max) divided by the surface area of the indenter $x$ squared penetration depth (h):

$$
H M V=\frac{F \max }{26.43 h^{2}}
$$

The Eit value was calculated according to the equation:

$$
\frac{1}{E r}=\frac{\left(1-v^{2}\right)}{E i t}+\frac{\left(1-v i^{2}\right)}{E i} \text {, }
$$

where $v$ and $v i$ are the Poisson's coefficient (defined as the property between the transverse and longitudinal specific deformations) of the sample and the indenter, respectively, and $E i$ is the elastic modulus of the indenter. The reduced Eit $(E r)$ was calculated by the equation:

$$
E r=\frac{\sqrt{\pi}}{2 \sqrt{A}} S,
$$

where $\mathrm{A}$ is the designed area for contact printing, $\mathrm{S}$ is the material stiffness obtained from the slope of the unloading curve, and $\pi$ is 3.14 .

In this study, HMV and Eit values were automatically calculated by the equipment software.

\section{Erosive $\mathrm{pH}$-Cycling}

After initial measurements, each of the 3 slices was subjected to a specific cycle of demineralization/ remineralization.

The demineralization of the slices was performed individually in 3 different solutions ( $n=9$ ): (1) $25 \mathrm{~mL} 0.3 \%$ citric acid, $\mathrm{pH}=3.25$ (adjusted with sodium hydroxide) under continuous stirring (70 rpm) at room temperature;

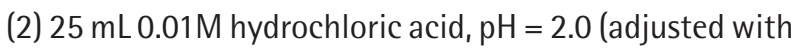
sodium hydroxide) under continuous stirring (70 rpm) at room temperature; and (3) deionized water. The groups were submitted to alternate periods of demineralization in 30-s steps and 1-h remineralization steps until $150 \mathrm{~s}$ of demineralization was completed. The remineralization was performed at $37^{\circ} \mathrm{C}$ in a way that the remineralization solution could be continuously stirred and samples would remain static. The remineralization solution contained
$0.7 \mathrm{mmol} \mathrm{CaCl}, 4.0 \mathrm{mmol} / \mathrm{L} / \mathrm{KH}_{2} \mathrm{PO}_{4}, 0.2 \mathrm{mmol} / \mathrm{L}, \mathrm{MgCl}_{2}$, $30 \mathrm{mmol} / \mathrm{L} \mathrm{KCl}$ and $20 \mathrm{mmol} / \mathrm{L}$ of 2-[4-(2-hydroxyethyl) piperazin-1-yl]ethanesulfonic acid (HEPES) buffering solution at $\mathrm{pH}=7$ and a $\mathrm{Ca} / \mathrm{P}$ molar rate of 0.125 (14).

After cycling, the HMV and Eit values were calculated as described above.

\section{Statistical Analysis}

Data of mechanical properties were submitted to a normality test and the means were compared using both three-way repeated-measures analysis of variance (ANOVA) and Fisher's protected least significant difference tests $(\alpha=0.05)$

\section{Results}

\section{Martens Hardness}

The results related to HMV values are in Table 2. After cycling with acidic solutions, the HMV values of dentin restored with all the evaluated adhesive systems decreased at all analyzed distances, regardless the presence of fluoride in the composition in these materials. For the samples restored with Single Bond 2, the lowest HMV values were found near the hybrid layer (at $10 \mu \mathrm{m}$ ) compared to the other distances, especially before the erosive cycling. These HMV values increased starting from the interface area, but after $30 \mu \mathrm{m}$, this difference was not statistically significant. Generally, for the One Up Bond F and Clearfil SE Protect self-etching adhesive systems, the HMV values did not show significant differences at the examined distances ( $p>0.05$ ), except for One Up Bond F before $\mathrm{pH}$ cycling and for Clearfil SE Protect after cycling with hydrochloric acid.

When the materials were compared, dentin restored with Adper Single Bond 2 showed the lowest HMV values before cycling at a distance of $10 \mu \mathrm{m}$, compared to the selfetching adhesive systems $(p<0.05)$. However, at $70 \mu \mathrm{m}$ from the adhesive interface, the difference was not statistically significant $(p>0.05)$. After cycling in water, the HMV value of dentin restored with One Up Bond Fadhesive was higher compared to Clearfil SE Protect at $10 \mu \mathrm{m}, 30 \mu \mathrm{m}$ and 50 $\mu \mathrm{m}(\mathrm{p}<0.05)$. After immersion in hydrochloric acid, the dentin hybridized with One Up Bond F had a higher HMV value compared to the hybridized dentin with Adper Single Bond $2(p=0.02)$ at $10 \mu \mathrm{m}$ distance. At the other distances (30 $\mu \mathrm{m}, 50 \mu \mathrm{m}$ and $70 \mu \mathrm{m})$, no significant differences in HMV values were found among dentin samples restored with different materials ( $p>0.05)$.

\section{Elastic Modulus}

The results related to the Eit values are in Table 3. In the restorations with the Adper Single Bond 2 adhesive system, only citric acid caused a significant decrease in the Eit values of dentin, especially at $50 \mu \mathrm{m}$ and $70 \mu \mathrm{m}$ from the 
bonded interface $(p<0.05)$. After cycling with hydrochloric acid, dentin restored with One Up Bond F adhesive showed lower Eit values at $30 \mu \mathrm{m}, 50 \mu \mathrm{m}$ and $70 \mu \mathrm{m}$ from the bonded interface, compared to samples stored in distilled water $(p<0.05)$. The samples restored with Clearfil SE Protect did not show significant difference in the Eit values either before or after immersion in hydrochloric acid and citric acid ( $p>0.05)$. When the distances of dentin restored with Adper Single Bond 2 were compared, no statistically significant differences in the Eit values among the analyzed distances were found $(p>0.05)$. For the samples restored with One Up Bond F, there was a decrease in the Eit values from the bonded interface after cycling in hydrochloric and citric acids, but beyond $30 \mu \mathrm{m}$ the difference was not statistically significant $(p>0.05)$. For the samples restored with Clearfil SE Protect, immersion in water and citric acid caused a decrease in the Eit values at $10 \mu \mathrm{m}$ and $30 \mu \mathrm{m}$ from the bonded interface $(p<0.05)$, but beyond $30 \mu \mathrm{m}$ these differences were not statistically significant ( $p>0.05)$. Before the erosive cycling, no statistically significant differences ( $p>0.05$ ) were found in the Eit values among the samples restored with different adhesives systems. However, after cycling in water, the hybridized dentin treated with the Single Bond 2 adhesive system showed lower Eit values

Table 2. Martens hardness (GPa) values (mean \pm standard deviation) of dentin before and after erosive $\mathrm{pH}$ cycling

\begin{tabular}{|c|c|c|c|c|c|}
\hline Material & Distance & Before & Deionized water & $\mathrm{HCl}$ & Citric acid \\
\hline \multirow{4}{*}{ Adper Single Bond 2} & $10 \mu \mathrm{m}$ & $0.50 \pm 0.16 \mathrm{Ba}^{\mathrm{C}}$ & $0.49 \pm 0.19 \mathrm{Aa}$ АВ & $0.31 \pm 0.12 \mathrm{Bb}^{\text {В }}$ & $0.34 \pm 0.16 \mathrm{Ab}^{\mathrm{A}}$ \\
\hline & $30 \mu \mathrm{m}$ & $0.62 \pm 0.22 \mathrm{Aa}^{\mathrm{B}}$ & $0.64 \pm 0.28 \mathrm{Aa}{ }^{\mathrm{AB}}$ & $0.43 \pm 0.14 \mathrm{ABb}^{\mathrm{A}}$ & $0.40 \pm 0.15 \mathrm{Ab}^{\mathrm{A}}$ \\
\hline & $50 \mu \mathrm{m}$ & $0.63 \pm 0.20 \mathrm{Aa}^{\text {B }}$ & $0.64 \pm 0.20 \mathrm{Aa}{ }^{\mathrm{AB}}$ & $0.49 \pm 0.18 \mathrm{Aab}^{\mathrm{A}}$ & $0.42 \pm 0.13 \mathrm{Ab}^{\mathrm{A}}$ \\
\hline & $70 \mu \mathrm{m}$ & $0.72 \pm 0.19 \mathrm{Aa}^{\mathrm{A}}$ & $0.64 \pm 0.20 \mathrm{Aab}^{\mathrm{A}}$ & $0.48 \pm 0.21 \mathrm{Abc}^{\mathrm{A}}$ & $0.40 \pm 0.14 \mathrm{Ac}^{\mathrm{A}}$ \\
\hline \multirow{4}{*}{ One Up Bond F } & $10 \mu \mathrm{m}$ & $0.64 \pm 0.14 \mathrm{Ba}^{\text {в }}$ & $0.66 \pm 0.25 \mathrm{Aa}^{\mathrm{A}}$ & $0.45 \pm 0.13 \mathrm{Ab}^{\mathrm{A}}$ & $0.35 \pm 0.10 \mathrm{Ab}^{\mathrm{A}}$ \\
\hline & $30 \mu \mathrm{m}$ & $0.70 \pm 0.17 \mathrm{ABa}{ }^{\mathrm{AB}}$ & $0.75 \pm 0.19 \mathrm{Aa}^{\mathrm{A}}$ & $0.45 \pm 0.15 \mathrm{Ab}^{\mathrm{A}}$ & $0.34 \pm 0.10 \mathrm{Ab}^{\mathrm{A}}$ \\
\hline & $50 \mu \mathrm{m}$ & $0.69 \pm 0.12 \mathrm{ABa}{ }^{\mathrm{AB}}$ & $0.81 \pm 0.34 \mathrm{Aa}^{\mathrm{A}}$ & $0.47 \pm 0.15 \mathrm{Ab}^{\mathrm{A}}$ & $0.41 \pm 0.12 \mathrm{Ab}^{\mathrm{A}}$ \\
\hline & $70 \mu \mathrm{m}$ & $0.78 \pm 0.22 \mathrm{Aa}^{\mathrm{A}}$ & $0.770 .18 \mathrm{Aa}^{\mathrm{A}}$ & $0.48 \pm 0.09 \mathrm{Ab}^{\mathrm{A}}$ & $0.39 \pm 0.10 \mathrm{Ab}^{\mathrm{A}}$ \\
\hline \multirow{4}{*}{ Clearfil SE Protect } & $10 \mu \mathrm{m}$ & $0.76 \pm 0.25 \mathrm{Aa}^{\mathrm{A}}$ & $0.44 \pm 0.15 \mathrm{Ab}^{\text {В }}$ & $0.41 \pm 0.10 \mathrm{Bb}{ }^{\mathrm{AB}}$ & $0.30 \pm 0.09 \mathrm{Ab}^{\mathrm{A}}$ \\
\hline & $30 \mu \mathrm{m}$ & $0.76 \pm 0.24 \mathrm{Aa}^{\mathrm{A}}$ & $0.49 \pm 0.16 \mathrm{Abc}^{\mathrm{B}}$ & $0.52 \pm 0.13 \mathrm{ABb}^{\mathrm{A}}$ & $0.33 \pm 0.11 \mathrm{Ac}^{\mathrm{A}}$ \\
\hline & $50 \mu \mathrm{m}$ & $0.79 \pm 0.24 \mathrm{Aa}^{\mathrm{A}}$ & $0.55 \pm 0.19 \mathrm{Ab}^{\text {В }}$ & $0.49 \pm 0.09 \mathrm{ABbc}^{\mathrm{A}}$ & $0.35 \pm 0.12 \mathrm{Ac}^{\mathrm{A}}$ \\
\hline & $70 \mu \mathrm{m}$ & $0.78 \pm 0.22 \mathrm{Aa}^{\mathrm{A}}$ & $0.60 \pm 0.22 \mathrm{Ab}^{\mathrm{A}}$ & $0.60 \pm 0.15 \mathrm{Ab}^{\mathrm{A}}$ & $0.39 \pm 0.17 \mathrm{Ac}^{\mathrm{A}}$ \\
\hline
\end{tabular}

Means followed by different letters (uppercase letters in the columns inside each material, lowercase letters in the rows and superscript letters for comparison among the materials in the same experimental condition), differ statistically from each other $(\mathrm{p}<0.05)$.

Table 3. Elastic modulus values (GPa) (mean \pm standard deviation) of dentin before and after erosive pH cycling

\begin{tabular}{|c|c|c|c|c|c|}
\hline Material & Distance & Before & Water & $\mathrm{HCl}$ & Citric acid \\
\hline \multirow{4}{*}{ Adper Single Bond 2} & $10 \mu \mathrm{m}$ & $26.35 \pm 11.43 \mathrm{Aa}^{\mathrm{A}}$ & $25.11 \pm 13.59 \mathrm{Aa}^{\text {В }}$ & $23.40 \pm 8.20 \mathrm{Aa}^{\mathrm{A}}$ & $21.23 \pm 9.94 \mathrm{Aa}^{\mathrm{C}}$ \\
\hline & $30 \mu \mathrm{m}$ & $24.21 \pm 6.55 \mathrm{Aab}^{\mathrm{A}}$ & $26.71 \pm 10.73 \mathrm{Aa}^{\text {В }}$ & $24.75 \pm 5.65 \mathrm{Aab}^{\mathrm{A}}$ & $19.84 \pm 5.80 \mathrm{Ab}^{\mathrm{B}}$ \\
\hline & $50 \mu \mathrm{m}$ & $23.15 \pm 5.51 \mathrm{Aa}^{\mathrm{A}}$ & $23.81 \pm 7.20 \mathrm{Aa}^{\mathrm{B}}$ & $22.44 \pm 4.08 \mathrm{Aa}^{\mathrm{A}}$ & $18.58 \pm 4.87 \mathrm{Ab}^{\mathrm{B}}$ \\
\hline & $70 \mu \mathrm{m}$ & $24.42 \pm 6.70 \mathrm{Aa}^{\mathrm{A}}$ & $23.60 \pm 6.62 \mathrm{Aa}^{\mathrm{B}}$ & $22.60 \pm 3.95 \mathrm{Aa}^{\mathrm{A}}$ & $17.98 \pm 4.80 \mathrm{Ab}^{\mathrm{B}}$ \\
\hline \multirow{4}{*}{ One Up Bond F } & $10 \mu \mathrm{m}$ & $29.44 \pm 13.11 \mathrm{Ab} \mathrm{A}^{\mathrm{A}}$ & $33.91 \pm 8.18 \mathrm{Ab}^{\text {В }}$ & $33.32 \pm 17.20 \mathrm{Ab}^{\mathrm{A}}$ & $49.69 \pm 13.38 \mathrm{Aa}^{\mathrm{A}}$ \\
\hline & $30 \mu \mathrm{m}$ & $26.24 \pm 5.92 \mathrm{ABb}^{\mathrm{A}}$ & $31.98 \pm 7.80 \mathrm{Aa} A \mathrm{AB}$ & $22.64 \pm 6.90 \mathrm{Bb}^{\mathrm{A}}$ & $27.39 \pm 6.44 \mathrm{Bab}^{\mathrm{A}}$ \\
\hline & $50 \mu \mathrm{m}$ & $24.93 \pm 4.24 \mathrm{Bb}^{\mathrm{A}}$ & $29.89 \pm 8.04 \mathrm{Aa}{ }^{\mathrm{AB}}$ & $22.03 \pm 6.00 \mathrm{Bb}^{\mathrm{A}}$ & $26.29 \pm 4.40 \mathrm{Bab}^{\mathrm{A}}$ \\
\hline & $70 \mu \mathrm{m}$ & $26.16 \pm 5.14 \mathrm{ABab} \quad \mathrm{A}$ & $29.19 \pm 3.91 \mathrm{Aa}^{\mathrm{AB}}$ & $21.57 \pm 2.96 \mathrm{Bc}^{\mathrm{A}}$ & $23.84 \pm 3.61 \mathrm{Bbc}^{\mathrm{A}}$ \\
\hline \multirow{4}{*}{ Clearfil SE Protect } & $10 \mu \mathrm{m}$ & $26.63 \pm 6.23 \mathrm{Ab}^{\mathrm{A}}$ & $52.90 \pm 28.11 \mathrm{Aa}^{\mathrm{A}}$ & $38.49 \pm 26.12 \mathrm{Aab}^{\mathrm{A}}$ & $35.58 \pm 13.77 \mathrm{Ab}^{\mathrm{B}}$ \\
\hline & $30 \mu \mathrm{m}$ & $25.36 \pm 5.21 \mathrm{Ab}^{\mathrm{A}}$ & $40.04 \pm 18.59 \mathrm{ABa}^{\mathrm{A}}$ & $29.16 \pm 17.66 \mathrm{Ab}^{\mathrm{A}}$ & $25.60 \pm 6.61 \mathrm{Bb}{ }^{\mathrm{AB}}$ \\
\hline & $50 \mu \mathrm{m}$ & $25.68 \pm 5.48 \mathrm{Ab}^{\mathrm{A}}$ & $34.38 \pm 11.31 \mathrm{Ba}^{\mathrm{A}}$ & $23.43 \pm 4.65 \mathrm{Ab}^{\mathrm{A}}$ & $23.52 \pm 4.68 \mathrm{Bb}^{\mathrm{A}}$ \\
\hline & $70 \mu \mathrm{m}$ & $25.01 \pm 4.58 \mathrm{Ab}^{\mathrm{A}}$ & $34.12 \pm 12.55 \mathrm{Ba}^{\mathrm{A}}$ & $25.26 \pm 4.80 \mathrm{Ab}^{\mathrm{A}}$ & $26.03 \pm 6.54 \mathrm{Bb}^{\mathrm{A}}$ \\
\hline
\end{tabular}

Means followed by different letters (uppercase letters in the columns inside each material, lowercase letters in the rows and superscript letters for comparison among the materials in the same experimental condition), differ statistically from each other $(\mathrm{p}<0.05)$. 
compared to dentin hybridized with Clearfil SE Protect $(p<0.05)$. After cycling in citric acid, the hybridized dentin treated with the Single Bond 2 adhesive system showed lower Eit values compared to dentin hybridized with One Up Bond $F(p<0.05)$.

\section{Discussion}

The design and conduction of this study were based on evidence that dental erosion occurs after repeated exposure of the dental substrate to gastric contents or acidic foods and drinks $(14,15)$. It was assumed that this acid exposure might also have an effect on restorative materials and their bonding interfaces. Since the conventional repair of eroded tooth surfaces usually involves enamel restoration with direct restorative materials, the effects of acid exposure on materials that contain fluoride should be investigated, as well as the effect of fluoride ion these materials in the underlying substrate. Studies that evaluated the effect of acid on dental surface and restorative materials used citric acid to simulate dental erosion of extrinsic origin, since this is the main acid in fruit juices, soft drinks and some confections, which justifies its use in this study (16). The $0.01 \mathrm{M}$ hydrochloric acid solution with a $\mathrm{pH}$ of 2.0 simulates a severe, high-risk condition for the formation and progression of erosive lesions (15). Additionally, although pure gastric acid has $\mathrm{pH}$ between 0.9 and 1.5 after episodes of vomiting into the oral cavity, seldom is this $\mathrm{pH}$ less than 1.5, due to esophageal buffering and saliva dilution (17). Thus, the use of hydrochloric acid in this concentration simulates more realistic clinical conditions.

After cycling with hydrochloric and citric acids, the HMV values of hybridized dentin decreased for all studied groups at all the analyzed distances. Therefore, the acid solutions used in the study were able to erode the samples, confirming the first hypothesis of the study. The low $\mathrm{pH}$ values of citric acid $(\mathrm{pH}=3.25)$ and hydrochloric acid $(\mathrm{pH}=2.0)$ are below the critical $\mathrm{pH}$ for dentin demineralization $(\mathrm{pH}=6.7)$, resulting in a reduction of the mineral concentration (18). Furthermore, the citric acid in soft drinks and fruit juices, a tricarboxylic acid, is able to dissolve the dentin substrate by its reaction with hydroxyapatite. The citrate ion is a chelating ligand and forms a soluble complex with calcium ions, which promotes further dissolution (16).

The assessment methods used in the research are useful for quantifying changes in dentin subjected to erosive challenges. Ultramicroindentation was used in the study because it is an extremely sensitive measurement for detecting the initial stages of dental tissues dissolution. In comparison to traditional microhardness test, the current depth-sensing indentation equipment in load and displacement resolutions allows the use of ultra-low loads (19). With this technique, it is possible to distinguish the dissolution of a substrate after smooth episodes of acid exposure and therefore this method has a high clinical relevance. The HMV and Eit values are mechanical properties that could be used to assess indirectly both demineralization and remineralization of hard tissues (20). This study evaluated the localized HMV value, which is based on both elastic and plastic deformation, and the Eit value of subjacent dentin to adhesive systems containing fluorides (at $10 \mu \mathrm{m}, 30 \mu \mathrm{m}, 50 \mu \mathrm{m}$ and $70 \mu \mathrm{m}$ from the adhesive interface). In general, the results show that the distance from the bonded interface was determinant in both HMV values for the Adper Single Bond 2 conventional adhesive system, and the Eit values for the One Up Bond F and Clearfil SE Protect adhesive systems, confirming the second hypothesis of the study.

For dentin restored with Adper Single Bond 2, it was observed that the lowest HMV values were found at 10 $\mu \mathrm{m}$ from the bonded interface before and after cycling with hydrochloric acid (Table 2). After cycling in deionized water as well as citric acid, the same phenomenon occurred, but no statistical difference could be found among the distances. The conventional adhesive systems, like Adper Single Bond 2, require prior etching of the dentin with $37 \%$ phosphoric acid, which may cause removal of the smear layer, the smear plug and the intertubular dentin mineral content to a depth of approximately 2-7 $\mu \mathrm{m}$ (21). After washing the etched substrate, the spaces around the collagen fibers are filled with water, through which the hydrophilic monomer of material could diffuse to form the hybrid layer (22). This demineralization, caused by phosphoric acid, is probably responsible for the lower HMV values in the regions closer to the bonded interface. Furthermore, the fact that the dentin demineralization is relatively small (approximately $7 \mu \mathrm{m}$ ) might also explain the higher HMV values found at distances greater than $10 \mu \mathrm{m}$. Unlike the conventional adhesive systems, the self-etching adhesive systems do not require the preliminary stage of acid etching the dentin. These materials have the so-called "self-etching primer" in their composition; their relative acidity is able to permeate between the constituent particles of the smear layer and penetrate into the subjacent dentin (22). This acid primer is not rinsed from the surface, so the demineralized smear layer is incorporated to the hybrid layer (23). Such differences in material composition and the consequent dentin demineralization could explain the maintenance of HMV values from 10 to $50 \mu \mathrm{m}$, for the dentin restored with One Up Bond $\mathrm{F}$ and Clearfil SE Protect for all evaluated groups (Table 2). In relation to the Eit values, different behavior was found between dentin restored using the self-etching adhesive systems, with their ability to release fluoride ions (One Up Bond F and Clearfil SE Protect) and the dentin restored using a conventional 
bonding system (Adper Single Bond 2). In the latter, there was a decrease in the dentin Eit values after immersion in citric acid as compared to the initial measurements, with statistically significant difference at the 50 and 70 $\mu m$ (Table 3). For dentin restored with Clearfil SE Protect, a significant decrease was found in the Eit values after immersion in acid solutions at all distances from the bonded interface compared to storage in distilled water (Table 3). After cycling in water, the dentin restored with Clearfil SE Protect showed higher Eit values compared to the dentin restored using Adper Single Bond $2(p<0.05)$. After cycling in citric acid, the dentin restored with One Up Bond F showed higher Eit values compared to the dentin restored using Adper Single Bond $2(p<0.05)$. These findings may be related to the possible ability of One Up Bond F and Clearfil SE Protect to release fluoride ions. According to Ferracane et al. (11), these released ions would penetrate and diffuse easily through the dentin walls, resisting the secondary caries lesions and erosion. Thus, the third hypothesis of the study was also confirmed.

After cycling in deionized water, the dentin restored with One Up Bond F showed higher HMV values than the dentin restored with Clearfil SE Protect (Table 2). According to Rawls (24), the different effects that materials have on the inhibition of demineralization depend on the solubility, the type of active component, and the phase (organic or inorganic) at which fluoride is added. The One Up Bond F adhesive system has a dicarboxylic acid radical at the end of the 11-methacryloyloxy1,1-undecanedicarboxylic acid (MAC-10) monomer molecule. The hydrophilicity provided by this radical probably allowed the dissociation of fluoride ions from the particles of fluorosilicate in an aqueous environment. Furthermore, the dicarboxylic acid radical has a buffering potential due to the capture of $\mathrm{H}^{+}$ and $\mathrm{OH}^{-}$ions, and this property may prevent the dentin demineralization after $\mathrm{pH}$ cycling (25).

The Clearfil SE Protect contains fluoride particles, while One Up Bond F contains fluoraluminosilicate glass particles. In cariogenic conditions or erosive challenges, these materials can release fluoride ions that improve mineralization and reduce demineralization of the dentin structure $(1,7)$. However, the release of fluoride ions decreases over time, thereby decreasing the protective capacity of these materials $(1,7)$. In the present study, the fluoride released has a more pronounced protective effect in the regions closer to the bonded interface. Itota et al. (9) and Han et al. (12) described this region as the acid-resistant layer and showed that with self-etching adhesive systems, inhibition of demineralization occurs mainly in the region adjacent to these restorations.

Despite the fact that fluoride released from adhesive materials could control demineralization and enhance its ability to prevent secondary caries and erosive lesions (25), their real effectiveness in a clinical setting is still questionable. Additionally, the adhesive system alone is not able to inhibit demineralization completely. The combination with other prevention methods must be considered for the prevention and control of the enamel erosion development.

\section{Resumo}

0 objetivo deste estudo foi avaliar o efeito da ciclagem de $\mathrm{pH}$ erosiva com soluções que simulam a erosão dental, na dureza Martens (HMV) e módulo de elasticidade (Eit) da dentina restaurada com sistemas adesivos contendo fluoretos. Vinte e sete blocos de dentina foram restaurados com três sistemas adesivos: sistema adesivo de condicionamento total Adper Single Bond 2 e sistemas adesivos autocondicionantes contendo fluoreto One Up Bond Fe Clearfil SE Protect. As restaurações foram realizadas com resina Filtek Z250. Os valores de HMV e Eit nas distâncias de 10, 30, 50 e 70 $\mu \mathrm{m}$ da interface foram avaliadas em ultramicrodurômetro dinâmico antes e após a imersão em água deionizada, ácido cítrico e ácido clorídrico $(n=9)$. Dados foram submetidos à ANOVA para medidas repetidas e Fisher PLSD $(\alpha=0,05)$. Após a ciclagem erosiva, os valores de HMV da dentina diminuíram em todos os grupos. Para a dentina restaurada com Adper Single Bond 2, os menores valores foram encontrados próximo a camada hibrida enquanto que, para os sistemas adesivos One Up Bond Fe Clearfil SE Protect, os valores permaneceram inalterados em todas as distâncias. Para a dentina restaurada com os materiais que liberam fluoretos, uma redução nos valores de Eit foi encontrada, mas após $30 \mu \mathrm{m}$ essa diferença não foi mais significante. As substâncias ácidas foram capazes de alterar a HMV e o Eit da dentina subjacente. Para os adesivos que liberam fluoretos, quanto maior a distância da interface adesiva, menor os valores de Eit. 0 fluoreto presente no One Up Bond Fe Clearfil SE Protect foi capaz de proteger a dentina subjacente próxima aos materiais. Dessa maneira, a presença do flúor em sistemas adesivos pode ter algum efeito positivo em estágios iniciais de lesões erosivas.

\section{Acknowledgements}

The authors would like to thank Dr. Juno Gallego from Department of Mechanical Engineering, Ilha Solteira School of Engineering - UNESP, for the use of DUH-211S dynamic digital ultramicrohardner (Shimadzu). This study was financially supported by CAPES.

\section{References}

1. Domiciano SJ, Colucci V, Serra MC. Effect of two restorative materials on root dentine erosion. J Biomed Mater Res B Appl Biomater 2010;93:304-308.

2. Amaechi BT, Higham SM. Dental erosion: Possible approaches to prevention and control. J Dent 2005;33:243-252.

3. Lussi A, Schlueter N, Rakhmatullina E, Ganss C. Dental erosion - an 
overview with emphasis on chemical and histopathological aspects. Caries Res 2011;45:2-12.

4. Packer CD. Cola-induced hypokalaemia: a super-sized problem. Int J Clin Pract 2009;63:833-835.

5. Wiegand A, Attin T. Occupational dental erosion from exposure to acids: a review. Occup Med 2007;57:169-176.

6. Shellis RP, Barbour ME, Jones SB, Addy M. Effects of $\mathrm{pH}$ and acid concentration on erosive dissolution of enamel, dentine, and compressed hydroxyapatite. Eur J Oral Sci 2010;118:475-482.

7. Pinto $C F$, Paes-Leme $A F$, Ambrosano GM, Giannini M. In vitro secondary caries inhibition by adhesive systems in enamel around composite restorations Oper Dent 2010;35:345-352.

8. Ayres APA, Tabchoury CPM, Berger SB, Yamautid M, Ambrosano GMB, Giannini M. Effect of fluoride-containing restorative materials on dentin adhesion and demineralization of hard tissues adjacent to restorations. J Adhes Dent 2015;17:337-345.

9. Itota T, Nakabo S, Iwai Y, Konishi N, Nagamine M, Torii Y. Inhibition of artificial secondary caries by fluoride-releasing adhesives on root dentin. J Oral Rehabil 2002;29:523-527.

10. Nakajima M, Okuda M, Ogata M, Pereira PNR Tagami J, Pashley DH. The durability of a fluoride-releasing resin adhesive system to dentin. Oper Dent 2003;28:186-192.

11. Ferracane JL, Mitchem JC, Adey JD. Fluoride penetration into the hybrid layer from a dentin adhesive. Am J Dent 1998;11:23-28.

12. Han L, Edward C, Okamoto A, Iwaku M. A comparative study of fluoride-releasing resin materials. Dent Mater J 2002;21:9-19.

13. Costa AR, Correr-Sobrinho L, Ambrosano GMB, Sinhoreti MAC, Borges $\mathrm{GA}$, Platt JA, et al.. Dentin bond strength of a fluoride-releasing adhesive system submitted to pH-cycling. Braz Dent J 2014;25:472478.

14. Lippert F, Parker DM, Jandt KD. In vitro demineralization/ remineralization cycles at human tooth enamel surfaces investigated by AFM and nanoindentation. J Colloid Interface Sci 2004;280:442448.

15. Hove LV, Holme B, Young A, Tveit AB. The protective effect of TiF4, SnF2 and $\mathrm{NaF}$ against erosion-like lesions in situ. Caries Res 2008;42:68-72.

16. Barbour ME, Parker DM, Allen GC, Jandt KD. Human enamel dissolution in citric acid as a function of $\mathrm{pH}$ in the range $2.30 \leq \mathrm{pH} \leq 6.30-\mathrm{a}$ nanoindentation study. European J Oral Sci 2003;111:258-262.

17. Francisconi LF, Honório HM, Rios D, Magalhães AC, Machado MAAM, Buzalaf MAR. Effect of erosive $\mathrm{pH}$ cycling on different restorative materials and on enamel restored with these materials. Oper Dent 2008;33:203-208.

18. Soares LE, Lima LR, Vieira LS, Do Espírito Santo AM, Martin AA. Erosion effects on chemical composition and morphology of dental materials and root dentin. Microsc Res Tech 2012;75:703-710.

19. Antunes JM, Cavaleiro A, Menezes LF, Simoes MI, Fernandes JV. Ultramicrohardness testing procedure with Vickers indenter. Surf Coat Technol 2002;149:27-35.

20. Shahdad SA, McCabe JF, Bull S, Rusby S, Wassell RW. Hardness measured with traditional Vickers and Martens hardness method. Dent Mater 2007;23:1079-1085.

21. Fleming PS, Johal A, Pandis N. Self-etch primers and conventional acid-etch technique for orthodontic bonding: a systematic review and meta-analysis. Am J Orthod Dent Orthop 2012;142:83-94.

22. Pashley DH, Carvalho RM. Dentine permeability and dentine adhesion. J Dent 1997;25:355-372.

23. Giannini M, Makishi $P$, Ayres APA, Vermelho PM, Fronza BM, Nikaido T, et al.. Self-etch adhesive systems: a literature review. Braz Dent J 2015;26:3-10.

24. Rawls AR. Preventive dental materials sustained delivery of fluoride and other therapeutic agents. Adv Dent Res 1991;5:50-55.

25. Kirsten GA, Takahashi MK, Rached RN, Giannini M, Souza EM. Microhardness of dentin underneath fluoride-releasing adhesive systems subjected to cariogenic challenge and fluoride therapy. J Dent 2010;38:460-468.

Received July 8, 2015

Accepted February 12, 2016 